\title{
Diagnosis of Evaluative Design Indicators of Pillars of Natural Energies in Architecture
}

\author{
Aisha Alaa Al-Qaissi ${ }^{1 *}$ Khalid Abdul Wahab Al-Mudares ${ }^{2}$ \\ 1. School of Architecture, Al Nahrain University, PO box 64074, Baghdad 10011, Iraq \\ 2. Professor in School of Architecture, Al Nahrain University, PO box 64074, Baghdad 10011, Iraq \\ * E-mail of the corresponding author: aysha.alaasalih@gmail.com
}

\begin{abstract}
Means of finding the energy sources adopted by man are developed generally with the development of creation. Also, they differed through the man's stages of civilized life as there is a mutual interaction between development of human civilization and energy sources. World's consumption of depleted energy increased especially in the period of second half of the twentieth century. Therefore, the demand for energy and guaranteeing its availability in buildings have increased. Oil became one of the most important sources of energy in the twentieth century, and it helped in the escalation of energy consumption rates which is categorized as a quite cheap source of energy in comparison with other sources of energy until the seventies of the last century where the crisis of energy has taken placed. This energy crisis has an environmental, economic and political dimension. However, the danger of oil depletion loomed over the world, and the energy crisis has become one of the most important problems the world was currently facing. The crisis of energy has appeared due to firstly: the large and continuous increase for consumption of energy which is matched by specific reserves of traditional energy sources, secondly: a significant increase in fuel prices and environmental problems caused by depleted energy sources. In this way, researchers have tried to develop new as well as alternative sources of energy. All the attention is directed to renewable energies, especially solar energy. In this respect, research and studies have begun to face the reality of the depletion of fossil fuels, and their replacement with renewable energy that is not depleted and it does not cause any environmental pollution. Consequently, the research problem reads as "Confused vision about the possibility of diagnosing the indicators of the pillars of active natural energies in architecture (active and passive)". Concerning the major objective of this research, it is summarized as follows: "Investigating the available constituents and characteristics of the natural energy systems and their indicators in Iraq in a way serves the beneficiaries, decision-makers and urban studies." Additionally, this research discusses some of the pillars of natural energies (passive and active), and their innovative planning and design systems in architecture. Besides, it studies some renewable energy systems alternative to depleted energy which include the use of solar energy, biomass, and ground mass. Furthermore, the research examines the effectiveness of passive systems to rationalize energy consumption which includes natural cooling, heating and ventilation systems in buildings, as well as shading, vegetation, afforestation, orientation, color and controlling the other potential internal heat sources.
\end{abstract}

Keywords: Renewable energy, environmental sustainability, passive and active air-conditioning, clean energy, zero pollution, zero-carbon architecture.

DOI: $10.7176 / \mathrm{JETP} / 11-4-06$

Publication date:September 30th 2021

\section{Introduction}

Renewable energy is any source of energy naturally renewed during a short period of time by any scale. It can be obtained from more than one source such as the sun, either directly through (heat, chemical photons, and electric photons) or indirectly such as energies of (wind, Biomass, tides, and solar energy stored in plants) or from other sources such as geothermal mass. It is worth to denote that the Energy Efficiency (EE) and Renewable Energy (RE) pillars are the two main pillars of sustainable energy. Therefore, these two pillars must be developed strongly to ensure the reduction of greenhouse gas emissions and to enhance their utilization efficiency which is necessary to slow the increasing demand for energy in general, which in turn reduces the consumption of depleted energy, as well as regulating the production of energy from renewable natural sources. A group of European researchers in (1996) have developed a charter for organizing the foundations of solar energy in all architecture and city planning projects. This charter was signed by (30) prominent architects at that time as a comprehensive attempt to deal with planning challenges, the focus has been on planning ecological cities, 
organizing their urban sites, designing buildings and ensuring the flexible construction process and the way it works, as a challenge to sustainable planning. Several directions appeared by the European Solar Energy Corporation (euro solar) in (2001) to be applied by local politicians in the projects of renewable energy. [1]

Interest in renewable energies was limited to developed countries until the early of 1990s then developing countries included as well. Renewable energy is a clean and environmentally friendly energy. The indicator of Rio Conference, which is a United Nations conference on sustainable development held in Brazil in the city of Rio Janeiro in (1992 A.D), explained that such a development cannot be achieved without changing the systems of the whole world. [2]

The above mentioned fact was confirmed also by the (Kyoto Protocol), which is a mandatory international treaty to reduce the amount of greenhouse gases emitted into the atmosphere by using fossil energy in the world.

Moreover, the cost of operating renewable energy systems is usually low, which makes its use a subject worth examination and application, as the great rise in fossil fuel prices in (2007-2008) led to an increase in investment in the renewable energy sector. The decline in prices at the end of (2008) and (2009A.D) was the main factor in reducing the amounts invested in that field. [2]

Iraq is one of the countries signed Kyoto Protocol for reducing the amount of greenhouse gases. Thence, the research problem has appeared which is "Confused vision about the possibility of diagnosing the indicators of the pillars of active natural energies in architecture (active and passive)" as long as with the research objective which is "Investigating the available constituents and characteristics of the natural energy systems and their indicators in Iraq in a way serves the beneficiaries, decision-makers and urban studies.

\section{Types of renewable energy sources}

There are many types of renewable energy sources in the world, but one or more of these sources may be available in some regions of the world including Arab countries. This research will deal with the types of renewable energy sources and their technologies in general and the focus is on (solar energy, biomass, and geothermal energy) for its importance on the domain of this research which is on (the available natural energies in Iraq).

\subsection{Solar Energy}

Iraq is located within the global solar belt between two circles of latitude to the north (29-37), and between longitudes to the east (38-48 degrees) which means that the range of the total energy of solar radiation reaches the central and southern regions of Iraq is between $(180-200 \mathrm{~km}) / \mathrm{Cm} 2)$, and in the northern regions it ranges between (160-180 kilocalories / cm2 per year), which is a very large amount compared to other countries of the world, as it ranges in the most hot European regions between (75-110 kilocalories / $\mathrm{cm} 2$ per year). In addition, the production of electrical energy from solar thermal energy is accomplished by the following modern technologies: [1]

\section{First: Parabolic Mirrors}

It is a new method for producing photovoltaic or thermal energy, and the main parts of the concave mirror system are as follows:

1. Concave mirrors: They are long rows of mirrors follow sun from east to west throughout the daytime, as shown in (Figure 1).

2. Absorber tube of solar radiation: It passes in the focal center of concave mirrors and contains inside it a kind of pure oils which absorb the heat reflected from those mirrors. The concentration of solar radiation is doubled by a rate ranging between (30-100) times on the absorbing tube and it is called the Concentration Ratio.

3. Boiler Heat Exchange: It contains water helps to absorb heat from the pure oils and the temperature can reach (400) degrees Celsius. The heat energy is transferred from the oil from the receiving tube to the water to reach the boiling point, and it transferred to a high pressure steam.

4. Turbine stations: Electric power is generated as a result of the conversion of thermal energy from the oil into kinetic energy by the high pressure of the steam then providing buildings with the produced thermal energy. [3]

The current research recommends the use of this system in Iraq. This is to produce photovoltaic energy or to produce hot water which can be used to provide heating by absorption heating systems. 

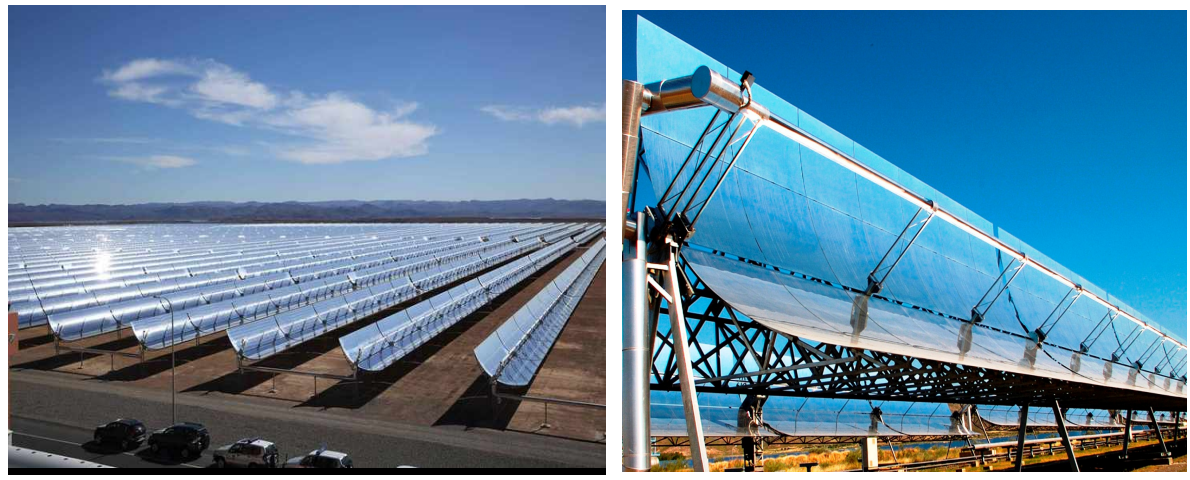

Figure 1: Concave mirrors one of system for producing electrical energy from solar radiation. Source : $[3, p .17]$

\section{Second: Solar Tower}

This system works by focusing the incident solar rays on regular rows of hundreds or thousands of flat mirrors, which track solar rays which are called heliostats. To focus, multiply, and reflect its normal rays to the equivalent of (1500) times at a central point at the top of a central tower located in the middle of the mirror complex, which contains heat exchangers and they are heat receivers for this system then it reaches to a thermal storage system. Using solar tower to generate steam, to rotate turbines to produce electric energy, and it can be used at the level of feeding cities .[4]

The research emphasizes on the importance of using this system to produce electric energy, or to produce hot water. It can be implemented in Iraq in open areas to produce electric energy for the city, and then transfer it through the infrastructure of power transmission networks. (Figure 2) illustrates the use of the solar tower in the production of renewable electric energy.
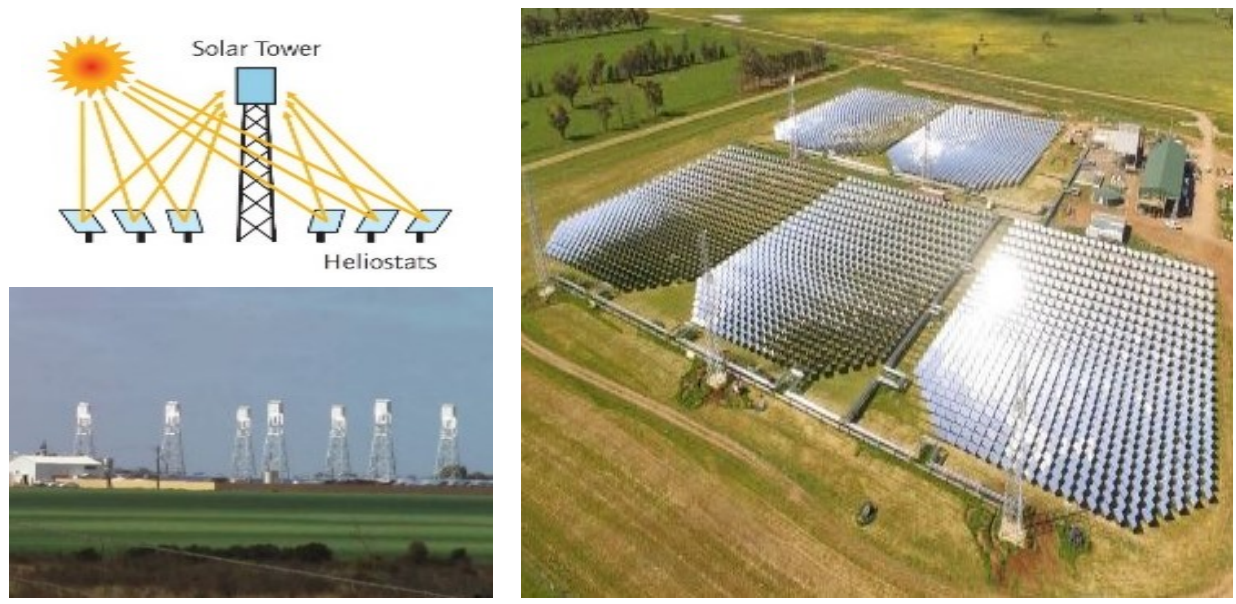

Figure 2 :Using the solar tower in in Sun drop, Australia with a capacity (100 MW) to produce renewable solar energy. Source: (https:/www.paginasiete.bo/revmiradas/2017/3/12/revolucioninvernaderos-high-tech-tomates-desierto-129663.html)

\section{Third: Parabolic Dish}

It is another model for generating electrical energy and its systems consist of a group of combined mirrors in the form of a dish, and they track the solar rays. Those mirrors focus the solar rays on a heat-receiving tube, which is 
installed at the center point of the dish, containing inside it a liquid (sodium) pressurized, where it is heated to a temperature that reaches $\mathrm{Up}$ to $(1000){ }^{\circ} \mathrm{C}$. This heat, in turn, evaporates the liquid sodium, expands and condenses on the heating tubes, and then works on converting the resulting mechanical energy into electrical energy by means of a turbine engine (Striling) or (a piston) placed in the center of the dish connected to the future tube, and works on the principle of using (Helium), and is linked to an electric generator that converts mechanical energy into electrical energy by increasing the temperature of the internal (helium) cycle. This is due to condensation (sodium) on the heating tubes which drives several (pistons) to generate electricity, as in (Figure3). (https://ar.wikipedia.org)

The research recommends on trying to produce electric energy in (Iraq) by using the technology of solar dishes, and installing it individually or in the form of groups or through large stations. It has the advantage of being an integrated system for the production of electrical energy, and it does not need other equipment or systems to accomplish its work for generating energy.
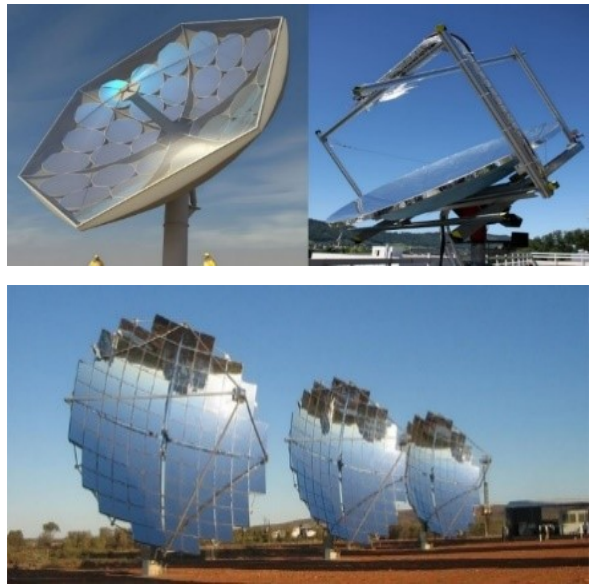

Figure 3 :Solar dish system to produce electric energy from concentrated solar radiation in Italy.

\author{
(http://www.progemaenergia.it/impianti-a- \\ concentrazione-solare-il-fotovoltaico-produce-di- \\ $\mathrm{piu} /$ )
}

\section{Fourth: Solar Chimney}

This system works on the concept of (The glass house) *, and the chimney is usually designed mainly in desert areas. This system contains a high central chimney surrounded by an area with glass walls and ceilings. The air inside the chimney is heated by solar energy to reduce its pressure and then the surrounding air rises by its higher pressure which is pushed strongly as a result of pushing the pressure upwards, through the solar chimney to the top, which usually contains (1-2) turbines with vertical or horizontal axes inside them, and works as a thermal accelerator. For electric power generation purposes. * (The glass house works by absorbing long solar thermal waves, and then converting them into thermal energy) .[4]

It is preferred to use this system in the vast desert areas of (Iraq). Because it is convenient, it does not require a complicated maintenance, it has a long operational life, it can be established in remote areas and finally it can be connected to the power transmission network to urban areas.

Fifth: Photovoltaics (PV)

The photovoltaic cell system is one of the most promising methods of generating energy, which converts the solar rays falling on those cells made of silicon, into electrical energy directly, as the input silicon produces an electric current (DC) when it is exposed to direct sunlight. The first uses were in the field of architecture, by placing solar panels on the roofs of buildings, near them or in the facades with the present time these cells have transformed to be an integral part of the building's structure, its creative and aesthetic architectural treatments, as in (Figure 4). [3] 
The research recommends the use of photovoltaic systems and solar collectors for the production of electrical energy or for the production of hot water, within the abandoned and neglected areas of the city, for example (in the remote desert areas in western Iraq (Anbar) and in the desert (Najaf) suitable for the implementation of these stations). This is to present the systems of renewable energy as part of the city and its infrastructure for energy production.

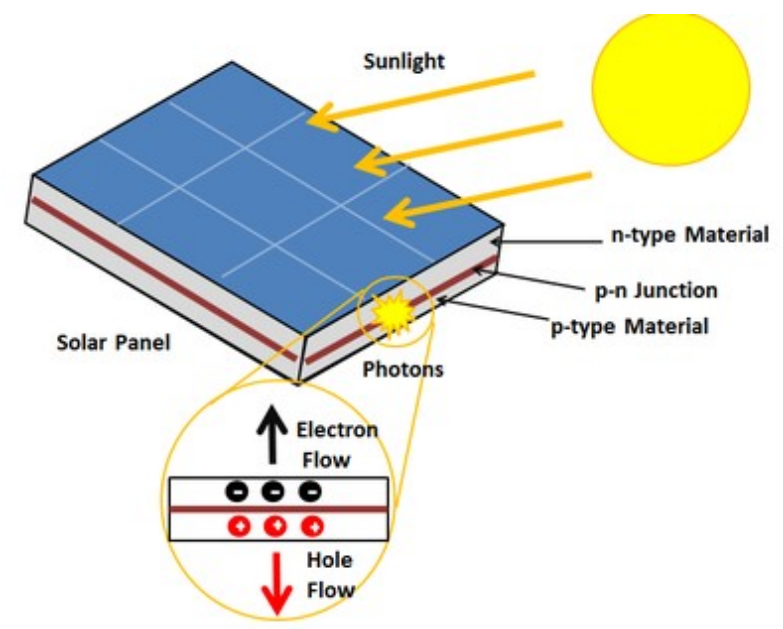

Figure 4: Illustration of the generation of electrical energy in a photovoltaic cell .Source:[6]

\subsection{Biomass energy}

It is considered one of the productive methods of renewable energy which reduces the negative environmental impacts of energy production. Furtherly, it reduces the amount of agricultural crop residues or wood and waste from industrial and food waste. This source can provide: electric energy, thermal energy, and liquid biofuel for vehicles (Bio fuel), as the main sources of biomass can be divided into two types as follows:

First: Natural (agricultural waste)

1. Energy crops: Plants are cultivated in large quantities for the purpose of energy production, and they include sugar cane and sugar beets.

2. Multifunctional crops: Plants can be used as food and as a source of energy, such as corn (Corn Grain).

3. Oily plants: plants can be used to produce oil. They are used to produce fuels, such as palm oil, soybeans, and algae are used for this purpose, there are trends consider algae a future plant and the possibility of implementing special fields on the roofs of buildings which forms a model for the idea of (the upper city).

4. Other plant wastes: such as: forest residues, agricultural residues of various types of trees, shrubs, herbs, wood, and industrial waste (for the manufacture of furniture, paper, and grain milling that leave many raw materials) it is considered the source of biomass.

These wastes are a source for producing electrical energy and thermal energy in an efficient and low cost manner, they reduce greenhouse gas emissions. They are available in various forms with modern technologies for their use. This makes biomass an attractive renewable source for energy production in many countries around the world .[4] 


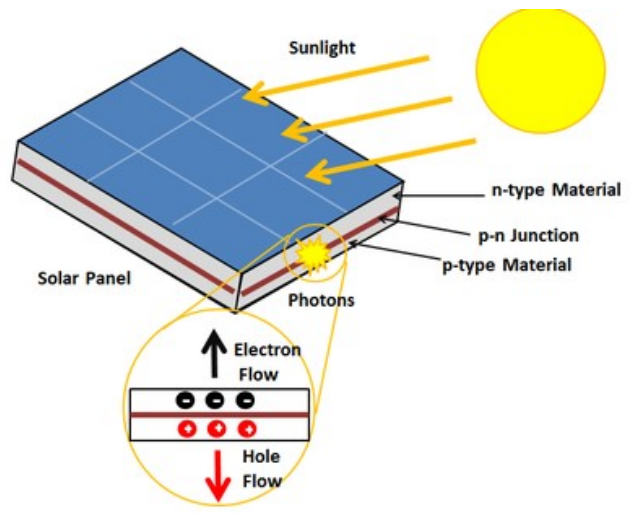

Figure 4:Illustration of the generation of electrical energy in a photovoltaic cell

.Source: [6]

Certainly the over-production of biofuels will lead to negative impacts on human food security which will result in dire economic consequences. The important thing here is to reduce competition between cultivating land for food crops and for the purposes of producing biofuels to a minimum, and this is what most major countries are working on.

Second: Human-made waste (waste, sewage waste, and animal farm waste)

It constitutes another important source of biomass and in light of the lack of use of waste as a source of energy and recycling, so the volume of global waste will continue to rise rapidly. The World Bank estimates that the world's production of about (2.2) billion tons of waste in (2025), i.e. almost double its current size of (1.3) billion tons. The negative impact of human-made waste on the environment can be reduced by collecting (land Fill gas: LFG) from landfill areas to produce a type of renewable energy source and this supports several factors, including:

- Safety in extraction of energy.

- Reducing the negative impacts of climate change.

The date palm tree is also the most widespread tree in the Arab world, especially in (Iraq) which in return produce large amounts of agricultural waste, such as palm fronds and other wastes. An adult palm can produce fronds upon regular pruning between (10-15) (Fronds) annually and the weight of each one is (2) kg before it dries up. The amount of water in it reaches to a $(65 \%)$ percentage of its weight, in addition to its production of about (10) (fruit holder), the weight of each one is (0.75) $\mathrm{kg}$, and about (2.5) $\mathrm{Kg}$ of fiber. Furthermore, an adult palm can produce about (25) $\mathrm{kg}$ of agricultural waste which is used as an energy source from biomass sources. A number of studies have also indicated that the date palm produces agricultural waste in the form of (date seeds) which constitutes a percentage reaches to $(10 \%)$ of the weight of the produced dates. To add this to the sources of biomass the palm can produce, as it may produce an amount of (35) $\mathrm{kg}$ of agricultural waste every year and this large amount of agricultural waste for one palm multiplied by the number of palms in (Iraq) which currently arrives to about (16 million) palm trees. Such a tree is a basic source of biomass ready for use as a renewable source for energy production in addition to other agricultural waste found in agricultural areas surrounding Iraqi cities especially in its center and south. This large untapped amount of biomass encourages implementation of production stations in these agricultural areas surrounding cities, located on the boundaries of urban areas, which are characterized by the following:

a. On one hand the stations are close to the source of raw materials. On other hand, they work to supply agricultural areas with energy.

b. They contribute in the implementation of renewable energy production stations in those areas which will help to develop these areas through the availability of job opportunities, and finding a source of income for the owners of agricultural areas by selling of agricultural waste of all kinds rather than being destroyed or disposed of as it actually happens.

c. The production of electric energy in agricultural areas helps in developing agricultural areas and reducing the load on the national electrical network. [9] 
Finally, the exploitation of the potential of Biomass energy of all kinds is a very important way to overcome the problem of obtaining energy because it is an important source of energy production, and its energy production continues around the clock. Therefore, biomass in its various types can be the best alternative for energy production from renewable sources, day and night. In addition, they covered a large part of energy demand in times when energy production from the solar source is lost, reduced, or when the sky is overcast. Thus, it will be an additional source to support this source in producing energy, provided that the production maneuvering takes place according to the current circumstances.

\subsection{Geothermal energy}

Many recent studies indicate another important source of renewable energy. This is done by exploiting the thermal energy of the interior part of Earth where it is estimated at about (99\%) of the mass of the Earth. The temperature increases as the depth of the core of Earth increases. Small and medium-sized geothermal pumps can be used vertically in any location for the purpose of generating thermal energy which can be used for heating in winter and cooling in summer.

The exploitation of geothermal energy is not available in (Iraq) now and in its form represented by the constant temperature thermal mass. However, there is a possibility to implement geothermal heat pumps to obtain heating, for cooling capabilities, or even exploit constant temperatures in the depths of the near earth which have been clearly exploited in Our Heritage Architecture.

\section{Indicators of passive conditioning systems in architecture}

The use of passive air-conditioning systems has expanded in recent times to the components of natural energies in architecture. It provides a thermal comfort to the occupants of the building as it can be used for the purposes of cooling hot areas in summer or heating in winter and then reduce the consumption of depleted energy. Global interest in the issue of passive air conditioning has increased clearly after the energy crisis of (1973) which indicated that the elements of the passive system can perform several functions including:

a. An architectural function as an element forms a part of the expressiveness and aesthetics of the building as well as its spatial context.

b. The function of collecting, storing and distributing the collected heat. [3]

Therefore, the focus in this paragraph will be on conditioning spaces because air conditioning is the most important problem in hot climates as is the case in all Arab countries, including Iraq. Most of the Arab regions have a hot dry season lasts for more than half of the year. As well as the emergence of new auxiliary building materials for the purposes of environmental protection and the direction towards some of the strategies and basics of the concepts of passive systems which were used in traditional architecture.

3.1 The most important indicators of the pillars of passive environmental protection for buildings and their groupings

First: The indicator of plants, afforestation and guaranteeing their standard proportions ... ecological

Trees and plants are effective means of providing natural space cooling and protection from solar radiation (direct or indirect).

The strategy of using trees, shrubs, weeds, and climbing plants in buildings and in the surrounding urban areas and its goal is summarized as follows:

- Reducing the influence of solar radiation energy which results in reducing the interior thermal gain of the buildings.

- This, in turn, reduces the consumption of energy required for air conditioning, it is reflected in reducing the potential of environmental pollution and reducing the use of exhausted energies for cooling purposes.

- Ensuring thermal comfort to the occupants of the building by reducing the internal temperature resulting from the activation of the concept of shading and evaporation.

- Afforestation is a factor of a great importance in regulating and mitigating the climate, as it helps to reduce the average of temperature of the surrounding buildings particularly its urban areas. 
- By means of (transpiration) in hot dry regions, plants work to release water vapor to the atmosphere. This increases its humidity and reduces the temperature of all surrounding areas, especially in hot-dry regions such as Iraq.

In addition, plants are a source of oxygen, a filter of air from dust and a key factor in ensuring the ecological balance of the whole city.

Second: The indicator of the relative relationship between the size of the building and the external area of its shell (S/V)

Architecturally, the shape of the cube is one of the most appropriate shapes in the architecture of hot dry regions, where the area of its outer shell reaches an almost minimum if its size is fixed, compared to elongated shapes (cuboid). In general, by increasing the number of outer faces of the same size of any shape, it will decrease gradually the area of its outer shell and the highest probability of multiple external aspects will give the least potential for the external space, reaching the spherical shape that gives the minimum for that value. Certainly spherical shapes are not ideal shapes in architecture except in some very specialized cases some hemispherical, circular and roofed with domes shapes, which are many in heritage architecture, are employed. Domed surface is suitable for hot and dry climatic conditions, which surface area increases relative to its horizontal projection and the roundness of the shape reduces the influencing solar thermal loads as a result of the emergence of passive air movement around the perimeter of the dome as a result of the differences in pressure between the sunny and shaded half of the dome. [13]

Some specialized studies in this field have proven the rectangular shape and close to the square with the lengths of its external dimensions, is one of the most suitable shapes in architecture and along the year in hot dry areas. The longitudinal increase is confined to the direction of the southern facade with a ratio of lengths not exceeding (1.6:1)

Third: the appropriate directive indicator for buildings and streets in hot dry regions

Geographical orientation plays an important role for each of the directions of buildings or streets in the city and two climatic principles are taken into account. The first principle is thermal gain of sunlight in winter and avoiding it in summer and the second principle is exposure to the prevailing air movement of the region, as the building may obtain an appropriate amount of thermal gain during the winter season and the least amount in summer, depending on the orientation of the building. Therefore, it is preferable to direct the building in a northsouth direction, and windows and building openings are preferable to the direction of good air movement in the area and face the prevailing winds and the exit vents for the wind managed in the opposite direction. [14]

Fourth: color reflectivity indicator of building facades (Albedo)

Visual specifications represented by the colors used in the dissolutions of building materials in hot dry regions have play an important role in the process of acquiring or reflecting the thermal radiation affected by it (Solar Radiation), which is more important than the optical aesthetic specifications (Optical Parameters). It is concluded that Tiles made of mosaic or alabaster and stone are among the coldest materials used in construction, and in terms of texture, tiles with smooth and flat surfaces were cooler than rough surfaces of the same type. The cool materials have a high reflectivity for short waves .[14]

We can deduct from this that the adoption of high-reflectivity colors reduces the thermal loads affecting the building facades. Also, the increase in the value of (albedo) in the facades of the buildings works to resist thermal gain more effectively and then it reduces the effect of heat islands (UHI) in all urban areas of the city.

Fifth: the building shading indicator

It is one of the advanced and used methods to reduce the thermal gain of the building. It includes shading part of the building's facade or its solid outer walls by means of trees and cultivated plants or by joining neighboring buildings as in compact heritage buildings or when using masks or solar breakers. In this way, each building shades the other adjacent or by roofs that cover part of the roof of the foundation building which is newly known as (Parasol Roof). Parasol roofs are suspended parts extend to protect from solar rays and rain and they are appropriate as well as beautiful in hot areas through the shadows formed from them and what follows from the change in temperature. Thus, they are a source of passive-energy. As for the internal shading systems, they are usually movable and foldable made of (Venetian blinds) or ordinary blinds and the use of breakers to protect the facades and the research indicates the most important ones :[16, pp. 2-20] 
1. Horizontal louvers: They are effective in the southern facades of hot dry areas. These horizontal louvers protect the protected spaces from the entry of solar rays in the summer and allow these rays which are relatively low to enter in the winter.

2. Vertical louvers: They are usually suitable for northeast and northwestern facades.

3. Egg-crate louvers: It is a double combination of horizontal and vertical crushers used in cases of insufficient horizontal or vertical breakers alone for the necessary shading. They are usually suitable for façades sandwiched between east-southeast or west and southwest.

4. Solar breakers and moving masks (Automated louvers): They are of high efficiency used for balancing the process of gaining or blocking heat during the different seasons.

Glass windows are the main source of thermal gain inside space and many attempts have appeared in the production of glass to reduce the transmittance of light and thermal radiation by means of manufacturing or packaging techniques including:

- Shaded Glass: It is the first type of color treated glass for shading.

- Low Emissivity Glazing Glass: It is known as (Low e-glass) and it is a modern type of transparent glass coated with multiple layers of different materials. From those layers the silver layer is used effectively to reflect the long infrared waves and to prevent radiation Ultraviolet from leakage to the inside.

- Responsive glass: It is the so-called (smart glass) which has selective permeability and it of three types:

a. A type related to a change in temperature (Thermochromic).

b. A type related to a change in the intensity of light (Photochromic). It is suitable for controlling the light radiation and the amount of luminance but not for thermal control. Actually, it only responds to the visible rays.

c. A type related to electro comic signals. It needs to be connected to the electrical system of the building.

- Prismatic glazing: It is a type of glass of a less transparent and it scatters more light than it is permeable to it. Besides, one of the two surfaces of the glass is serrated and it consists of a group of triple prisms. Its outer surface is designed in a way allows rays to enter towards its inner surface and it reflects back toward different angles of space. Thereby, a good selectivity of light is achieved, but it impedes the ability to see outward. [17]

\subsection{The most important anchor indicators of passive technologies of cooling and heating}

These technologies are built on the basis of balancing the heat transfer between the building and the surrounding thermal energy basins. One of those surrounding basins is the energy of (air, water, earth, sun, and sky) which have lower or higher temperatures. Whenever, the land mass is the thermal pool of the energy source the cooling process is known as (ground conditioning). By using water in the process, it is known as (cooling by convection and evaporation) and the sky is the cooling basin. That technique is called (radiative cooling) and the research below deals with some of the indicators of these techniques:

First: Earth Cooling Technology Indicator

In this strategy, static earth energy is used as a heat sink. Therefore, the building is constructed in connection with the subsoil as in the case of (traditional heritage basement), where the building is linked, even partially, with the subsoil of the land mass, to become a source of passive cooling for its structure. This is as a result of connecting the building spaces with the ground and to ensure the transfer of geothermal energy from the surrounding soil through special pipes or through cavities or shafts towards the building spaces by the Convection method. [19]

\section{Second: Load Cooling System Technology Indicator and Fumigation}

In this system, air is cooled by evaporation of water in water bodies or water flowing through fountains usually found in courtyards or evaporation produced by plants when the air current passes through their branches and leaves, which works to evaporate the water. The fountains were an essential element in the design of the central courtyards, whether in Arab Islamic architecture or in European architecture. It is an effective model fits natural climatic. [20]

\section{Third: Indicator of passive natural ventilation cooling system technology}

It is an efficient way to make use of the natural outdoor airflow. It is used for the purpose of cooling the building spaces, and to achieve thermal comfort for the occupants of the space in the case that the average outdoor air temperature is less than (33) degrees Celsius. It ensures cooling of the building's structure in general and cooling 
the internal spaces. This is as a result of the penetration of moderate air movement through the window openings directly, or through the openings of the wind tower for the air pedicure in the direction of the ventilation to feed the building spaces, including the basements and all the internal spaces,[21] Thus, the feeding wind tower is the basis for ventilating the various spaces of the building and making the windows such as air escapes or for the purposes of balancing the air pressure in order to ensure the flow of a continuous air current and the wind tower may work when the temperatures are high in the tops of the building above (33) degrees Celsius as a drag of air currents from the perimeter of the building or from the spaces of the basements and shaded alleys, which are usually of high pressure and are pushed through the a wind tower of the garage towards the top of the building, in order to ensure passive natural ventilation by the difference in pressure.[22]

The search in the next paragraph will attempt to review the abstract of the theoretical framework in a tabular format for the most important indicators of passive conditioning systems in architecture (Table 1), which can act as a measure ruler for the purposes of statistical evaluation and comparison of existing or proposed project.

\section{An abstract of the pillars and indicators of passive air-conditioning systems in architecture}

Table 1. Extracting statistical evaluation indicators of the pillars of passive air-conditioning systems in architecture - Source: (the researcher).

\begin{tabular}{|c|c|c|c|c|c|c|c|}
\hline \multirow[t]{2}{*}{ N. } & \multirow{2}{*}{$\begin{array}{l}\text { The basic pillars and their passive evaluative } \\
\text { indicators }\end{array}$} & \multirow[t]{2}{*}{ Code } & \multicolumn{5}{|c|}{ Evaluation results } \\
\hline & & & $\begin{array}{c}\text { Excellent } \\
1\end{array}$ & $\begin{array}{l}\text { Very } \\
\text { Good } \\
2\end{array}$ & $\begin{array}{c}\text { Good } \\
3\end{array}$ & $\begin{array}{c}\text { Acceptable } \\
4\end{array}$ & $\begin{array}{c}\text { Weak } \\
5\end{array}$ \\
\hline 1 & $\begin{array}{l}\text { The passive environmental protection anchor } \\
\text { for buildings and their assemblies }\end{array}$ & $\mathbf{A}$ & & & & & \\
\hline 1.1 & $\begin{array}{l}\text { The index of plants and afforestation and ensuring } \\
\text { their standard proportions ... ecological }\end{array}$ & $1-\mathrm{A}$ & & & & & \\
\hline 1.2 & $\begin{array}{l}\text { The indicator of the relative relationship between } \\
\text { the size of the building and the external area of its } \\
\text { shell }(\mathrm{S} / \mathrm{V})\end{array}$ & $2-\mathrm{A}$ & & & & & \\
\hline \multirow[t]{2}{*}{1.3} & \multirow{2}{*}{$\begin{array}{l}\text { Geo-direction indicator: } \\
\text { Appropriate geographical orientation of buildings } \\
\text { and their grouping } \\
\text { Appropriate geographical orientation to the main } \\
\text { residential streets }\end{array}$} & $3-\mathrm{A}$ & & & & & \\
\hline & & $4-\mathrm{A}$ & & & & & \\
\hline 1.4 & Reflectivity of materials index on building facades & $5-\mathrm{A}$ & & & & & \\
\hline \multirow[t]{2}{*}{1.5} & $\begin{array}{l}\text { Building a shading indicator } \\
\text { Guarantee of louvers and sun masks in the building } \\
\text { facades. }\end{array}$ & $6-\mathrm{A}$ & & & & & \\
\hline & $\begin{array}{l}\text { Guarantee of smart glass for exterior windows } \\
\text { (Shaded, Low Emissivity , responsive, and } \\
\text { prismatic) }\end{array}$ & $7-\mathrm{A}$ & & & & & \\
\hline 2 & $\begin{array}{l}\text { pillars for passive cooling and heating } \\
\text { technologies }\end{array}$ & B & & & & & \\
\hline 2.1 & Ground cooling system technology indicator & $1-\mathrm{B}$ & & & & & \\
\hline 2.2 & $\begin{array}{l}\text { Load cooling system technology indicator and } \\
\text { fumigation }\end{array}$ & $2-\mathrm{B}$ & & & & & \\
\hline
\end{tabular}


2.3 Indicator passive natural ventilation cooling 3 -B system technology

Notes:

- The basic pillars and their statistical evaluation indicators on the effectiveness of passive conditioning systems in architecture were extracted and diagnosed depending on a group of specialized studies and research, which are presented in the theoretical framework. In addition, taking the opinions of stakeholders and experts in the field of the environment, to ensure their importance and priority of effective indicators.

- The evaluation can be determined by the researcher exclusively after reviewing the detailed description of the projects selected for evaluation.

- Maximum evaluation score $=50$ points.

- The evaluation results are determined in relation to the number of points abstracted to the maximum degree of evaluation, as follows:

$$
\begin{aligned}
& \% 80-\% 100=\text { excellent. } \\
& \% 70-\% 79=\text { very good. } \\
& \% 60-\% 69=\text { good. } \\
& \% 50-\% 59=\text { acceptable. }
\end{aligned}
$$

What is less than 50 times.

\section{A review of some green projects distinguished by their passive and active natural systems.}

The first project: The international project of King Abdullah University of Science and Technology: KAUST project in Saudi Arabia - Thuwal city was established in (2009 A.D) for postgraduate studies.

It is considered the best example in organizing natural ventilation. The central collector space of the university city plays the role of distributor of movement, a center for natural ventilation, a student gathering area and a rest area which won the American Institute of Architects (COTE) / (AIA) award in (2010 A.D) for the best (10) Green projects. Also, it won (LEED Platinum) * certification to reduce the consumption of depleted energy by integrating a series of planning strategies in it and making sustainable building in the context of a very hot and humid climate. The project employed a set of contextual strategies borrowed from local culture and community traditions to solve local environmental issues. Hereby, an explanation to the most usable environmental factors of KAUST Project Systems: (https://ar.wikipedia.org) * (LEED Platinum) which is the highest rating in the green building classification system in the United States of America.

- The central pedestrian axis is cooled in the project by using a set of a Solar Chimney stack to create passive airflow in pedestrian paths and student rest and gathering areas.

- Solar panels covering most of the surfaces have also been employed for the availability of renewable energy for the project site.

- Exceptionally, local evaporative cooling was used in the project in hot dry weather conditions by creating green roofs, water bodies and fountains throughout the site.

- Using recycled condensers and equipping the central pedestrian axis with condensers from refrigeration equipment.

- Smart insulated glass curtain walls are adopted in all building facades.

- All the glass that is exposed to direct sunlight, as well as the skylights in the campus buildings were shaded in a similar way to the mashrabiyas in the traditional Saudi Arabian city and by using the mud system in the form of narrow rectangles designed specifically for the project. It is an integrated shading system with the building to reduce thermal gain while simultaneously passing the dramatic dim lighting.

- The openings of the central pedestrian axis have also been directed towards the sea to allow the passage of fresh air and the prevailing western breezes (sea and land breeze).

- As is the case with the compact urban fabric of traditional Saudi Arabian cities, the campus area has been compressed and its sections joined together as much as possible to reduce the areas of the outer envelope of the buildings which are usually exposed to sunlight and their heat loads as well as reduce walking distances 
similar to traditional markets which main streets were shaded. As in (Figure5). (https://www.kaust.edu.sa/ar/about/green-campus)

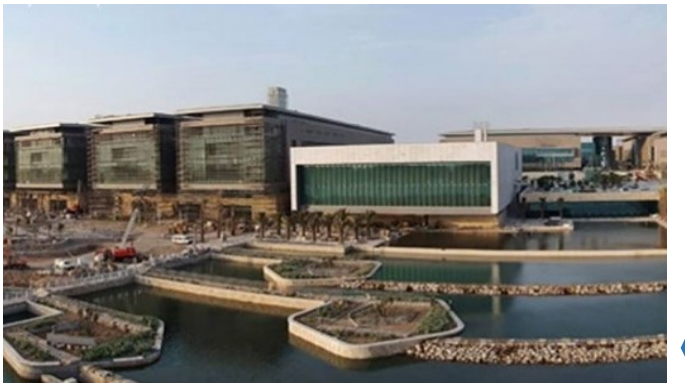

pulled of hot and corrupt air from the central gathering area through solar chimneys.

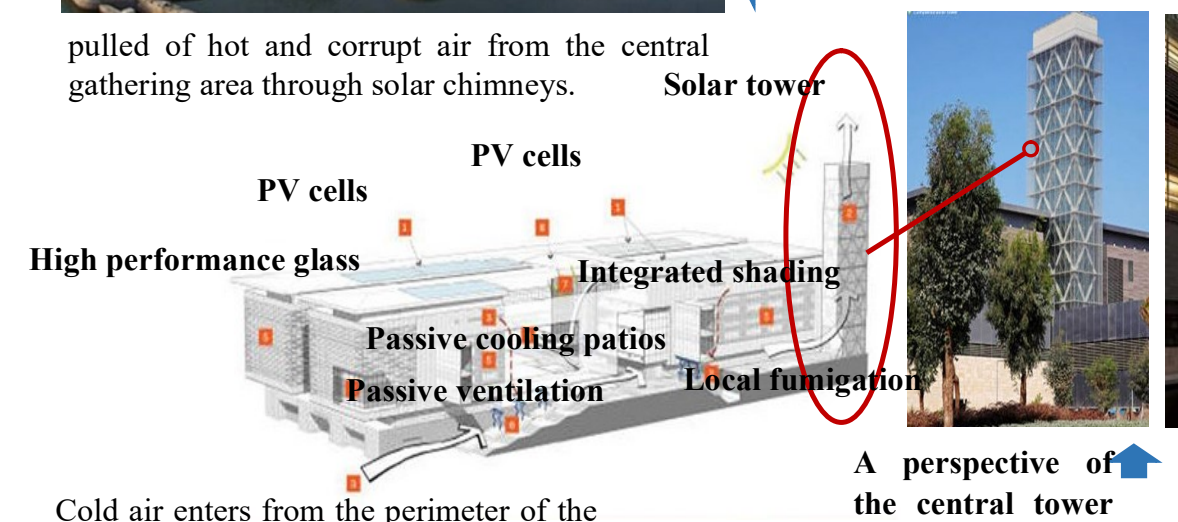

Cold air enters from the perimeter of the buildings to replace hot air coming ou ${ }^{+}$ the building spaces. movement paths.

\section{.}

\section{.}

(atrium) compact site plan

The design process shows a response to local climate, wind breeze and passive air

\section{Perspective of the university buildings}

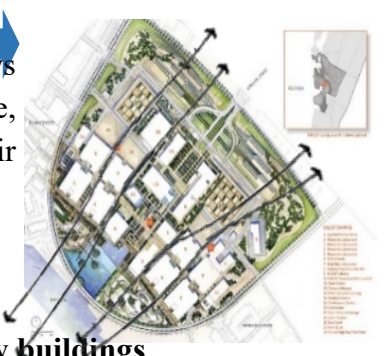

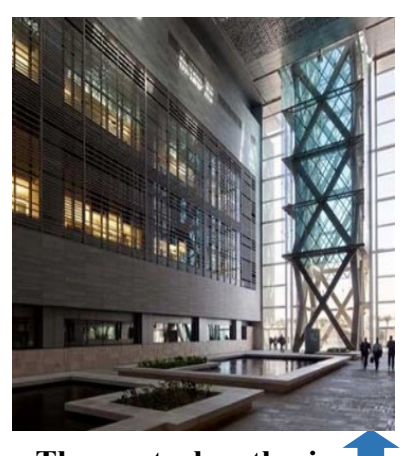

The central gathering area is the central movement and ventilation area.

The most important sustainable elements empioyed in university buildings

\section{PV cells}
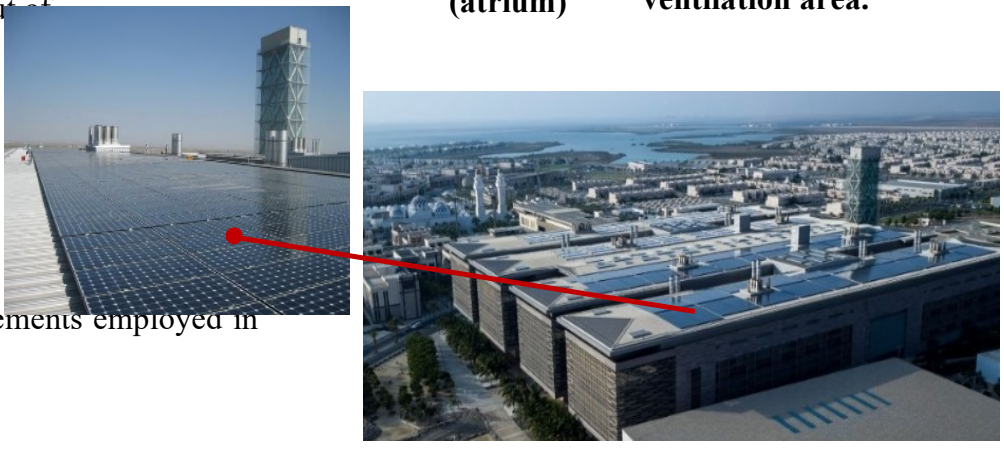

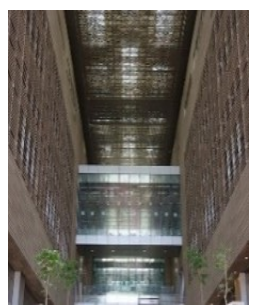

Clay system

to reduce

thermal gain

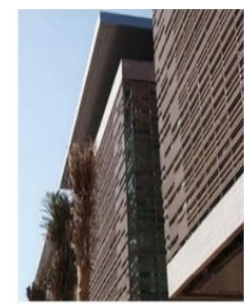

The integrated shading of the facades

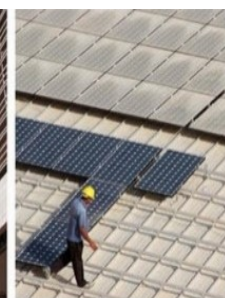

High performance photovoltaic roof

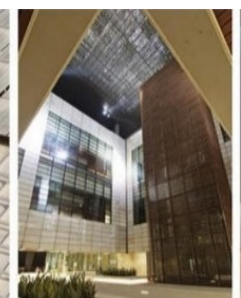

Passive cooling patios

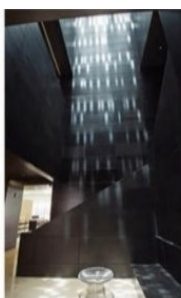

Filtering sunlight through smart windows

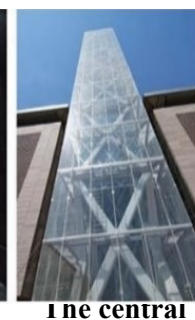

tower

(atrium)

Figure 5: The King Abdullah University for International Science and Technology (KAUST) project, its environmental pillars, and its uses of natural ventilation.

Source: the researcher's organization, depending on the source(https:/www.kaust.edu.sa/ar/about/green-

$$
\text { campus) }
$$


The second project: the cultural center project JEAN MARIE TJIBAOU) in the island of New Caledonia - the South Pacific (eastern Australia) (Kanak culture) - was opened in (1988 A.D), designed and revived by the Italian architect (Renzo Piano).

The research also shades the lights on another important example in the field of green building strategies, which is the JEAN MARIE (TJIBAOU) cultural center on the island of New Caledonia for Italian architecture (Renzo Piano). The region has a hot-humid climate the temperature ranges between (25-32) a Silesian degree. It is a project on a museum, library, conference center, performing arts, research and development centers and studios for (music, dance, painting and sculpture). The buildings of the center were designed in the form of wind tower through the roof and double walls. The passive air can be entered or taken out between the buildings naturally (thermal chimney) as the outer layer of the double walls is made of wooden pieces imitating the traditional Kanakian architecture in that region and the second layer is of smart glass surrounding it. So, the area between the two walls works as a solar chimney to draw the accumulated air between the two walls from the front of the building to the top to be replaced by cool air from the garden environment. Thus cooling its internal spaces, just as the double outer wall works (making the wind towers) by introducing the cold wind to the air gap from the bottom of the double wall at appropriate times, especially since its roof is also double facilitated the circulation of air through its two layers to the entire shell of the building, reducing the thermal loads in the center spaces, as well as using the protruding or roofing surfaces for its shading, landscaping, and water bodies in all its external corridors to ensure the availability of natural evaporative cooling and passive ventilation throughout the building. This is to achieve thermal comfort for its occupants, within a modern architecture compatible with the traditional Kanakian architecture of that region, and among the treatments is the use of local wood for the external veneer of the double wall, as shown in (Figure 6). (https://en.wikipedia.org)

The double wall acts as a wind tower for suitable air
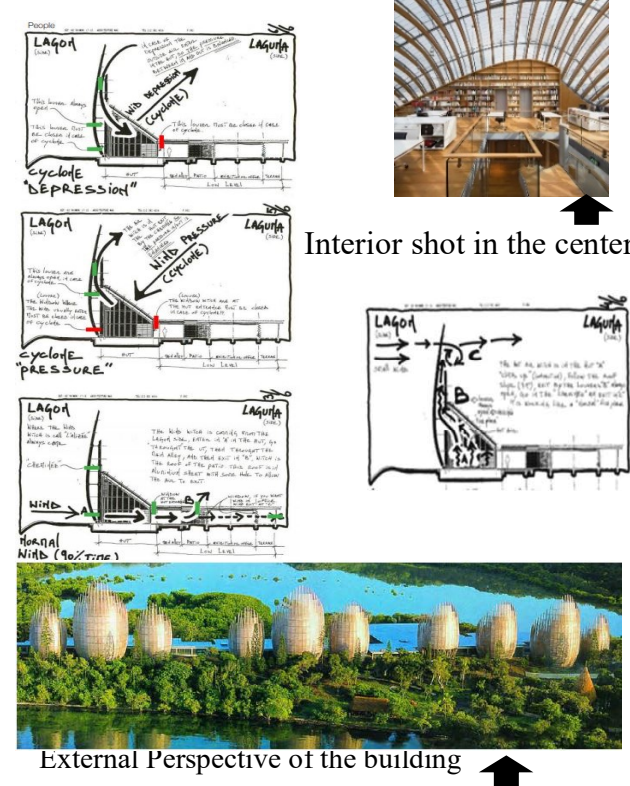
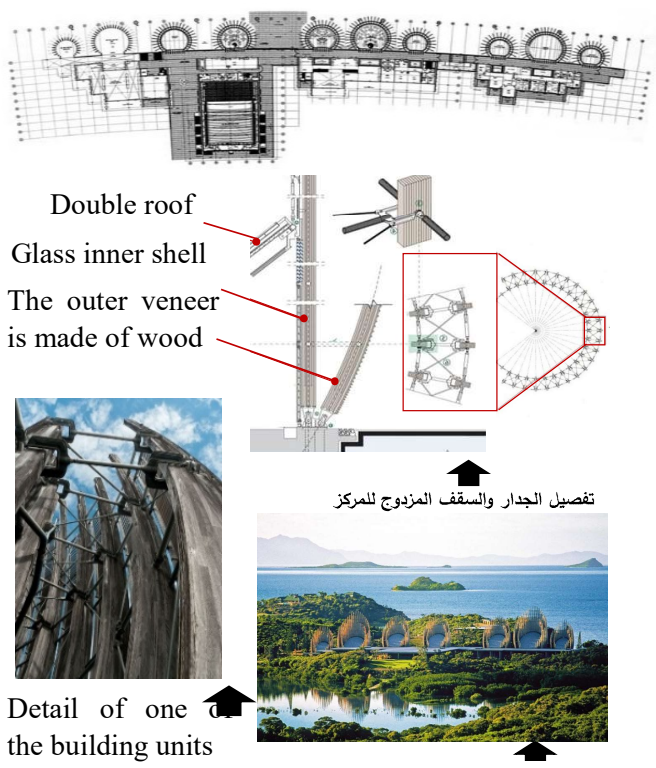

Perspective of the building

Figure 6: JEAN MARIE TJIBAOU Cultural Center in Caledonia by Renzo Piano

Source: the researcher's organization based on the source (https://en.wikipedia.org)

\section{Conclusions}

- Although some major countries refused to sign a $(\mathrm{CO} 2)$ gas production agreement, in the field of industry and construction, at the Montreal Conference held in Canada in (1987) by the world's leading architecture pioneers. Researchers in this field began to reduce relying on depleted energy sources instead they have 
introduced new alternatives to the natural energy components, in the areas of heating, cooling and ventilation and as an attempt to bring the necessary energy to zero carbon level.

- From this standpoint, the components of renewable natural energy have become one of the most important sources of energy today and in the future. They are available, cheap, safe, and they achieve self-sufficiency in energy needs, especially through the exploitation of thermal and photovoltaic solar energy, biomass energy, subsoil energy, wind energy and tides. As an attempt to gradually get rid of dependence on depleted energy and start a new era based on environmentally on clean friendly energies through which depleted energy will be replaced with a permanent renewable energy.

- Knowing that the principles of using renewable natural energies have a long history and they include most living creatures, in hot, cold and temperate regions. This is for the purpose of obtaining thermal comfort inside homes, work sites as well as the gathering and external movement sites of the human being wherever he is. This principle was evident in the Arab-Islamic architecture which is a result of the harsh climate, its extremism and the length of its hot season. Such a climate made Arab architecture use all kinds of passive cooling methods to become a distinctive mark in our Arab architecture and a way to quote and for all countries of the form east to west.

- Thus, the concepts of passive conditioning in the field of construction and industry became numerous. The components of nature, with its green surfaces, trees, forests and water have become effective items for the protection of man, his communities, his movement paths, and the sites of his residence in order to ensure thermal comfort for all seasons and year-round. These items have become one of the basics of environmental protection, in addition to its expressive and aesthetic indicators which were developed by the great pioneers of architecture over time.

- The oceanic thermal basin of natural energy sources (air, water, land, sun, and sky) has also become one of the basics of passive conditioning operations, and its contemporary technologies that include: ground cooling, convection cooling, evaporation, ventilation and radiative cooling.

- There are multiple contemporary studies and research in current field to ensure maximum utilization of the aforementioned modern technologies, especially in the field of utilizing thermal and photovoltaic solar energy, through concave mirrors, solar towers and plates, the effectiveness of the solar chimney and the thermal chimney.

- Photovoltaic systems have also been widely proposed for their industrial advantages and speed of production in obtaining electrical energy, which after its development, has become a widely used technology in large industrial buildings and housing sectors plus its aesthetic and creative uses, especially after it became possible to store it for the winter seasons, or transmitted by power transmission networks.

- Solar energy, biomass energy, and geothermal energy are widely available in Iraq and along the year. There are many factors in Iraq encourage the use of solar energy and its distinct characteristics in its high intensity, length of its daily and annual hours especially at noon and the times of hot seasons due to their close availability for the general geographical areas in Iraq.

- From this standpoint, the research confirms the possibility of expanding the production of electric energy and thermal energy for heating, cooling and lighting purposes to fully include all sectors of Iraqi cities depending on the local solar energy source. There is a possibility of expanding the field of energy production from solar energy sources in remote, abandoned, and untapped desert areas, such as the Western Sahara and the southern desert of Iraq. In these deserts vast areas of currently vacant land are available to make use of this great renewable energy to live up to an alternative investment wealth that is no less important than oil energy.

- Biomass energy can also be widely used in Iraq. This is because it possesses large quantities of biomass, especially in palm tree residues and the possibility of using the energy of the earth's interior. The temperature is relatively constant throughout the year for heating and cooling purposes despite of the limited use of this method relative to the general population.

- From this standpoint, the research vision in this research is clear from the potential of natural energies (active and passive) in producing sustainable Iraqi cities. 


\section{References}

[1] Fakhraldin and S. Mohammed, Design of a solar cooling system for Iraq Climate, Plymouth, England, UK: University of Plymouth Research Theses Research Theses Main Collection, 2016.

[2] S. Sciuto, "SOLAR CONTROL:An integrated approach to solar control techniques," Renewable Energy, 1998.

[3] K. Piech, "Renewable Energy Source, Biomass Energy," Publication (AGH) University of Science and Technology, Poland, 2010.

[4] M. Santamouris and etal, "Energy Policy and Action Plan for Renewable Energy Sources (RES), for the Hellenic Islands of the North Aegean Region," Energy, 1999.

[5] S. Gößling-Reisemann, "Resilience - Preparing Energy Systems for the Unexpectedi," in IRGC (2016) Resource Guide on Resilience., Bremen, Faculty of Production Engineering; Institute for Advanced Energy Systems; Sustainability Research Center ( $\operatorname{artec}$ ), University of Bremen, 2016, p. 8.

[6] P. Zhua and D. Yana, "Adapting LT-Method for Building Energy Prediction in China," a Department of Building Science, School of Architecture, Tsinghua University, Beijing 100084, China, 2017.

[7] V. Dlyay, "Design with Climate," New Jersay, 1963.

[8] Zhou and A. Jingjing, "Comparison and analysis of energy consumption of four office buildings in China and America," Building Science, 30(6), China, 2014.

[9] H. M. Talebn, "Using passive cooling strategies to improve thermal performance and reduce energy consumption of residential buildings in U.A.E. buildings," Higher Education Press, pp. 154-165, 22 January 2014.

$$
\begin{aligned}
& \text { البزاز, "توظيف الطاقة الثمسية في الأبنية في العراق," كلية الهندسة-جامعة بغداد, بغدادـ العراق, } 1990 \\
& \text { شاهين, "الثكل و العمارة في المناطق الحارة الجافة," دورة التعليم المستمر -جامعة بغداد/ كلية الهندسة , } 1989 \\
& \text { فتحي, "الطاقات الطييعية والعمارة التقليدية," المؤسسة العربية للار اسات والنشر, بيروت, } 1988 \\
& \text { مدونة العزل الحراري العر اقية, وزارة الإعمار والإسكان، الهيئة العامة للمباني، وزارة التخطيط، الجهاز المركزي للتقييس والسيطرة } \\
& \text { النوعية, بغداد, } 2013 . \\
& \text { المدرس، التكييف المنفعل للمنشآت العامة في المناطق الحارة الجافة، بغداد: كلية الهنسةفي جامعة بغداد، } 2008 .
\end{aligned}
$$

\section{Internet sources}

15. www.cpast.org/Articles/fetch.adp?topicnum=11/(1998)

16. http://helioscsp.com/israels-121-mw-ashalim-plot-b-concentrated-solar-power-plant-set-for-50expansion/(14-07-2015).

17. https://ar.wikipedia.org/ (1990)

18. http://www.progemaenergia.it/impianti-a-concentrazione-solare-il-fotovoltaico-produce-di-piu /(2013).

19. https://www.kaust.edu.sa/ar/about/green-campus/ (2021).

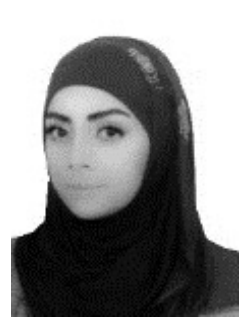

Aisha Al-Qaissi was born in Baghdad, on the second of January, (1990). She received her Bachelor from the Department of Engineering Architecture at Al-Nahrain University, Iraq, in (2013), and Master's student in Department of Engineering Architecture from Al-Nahrain University, Baghdad, Iraq in (2020).

She is currently works as a teacher assistant at Al-Farabi University. Her main research interests include sustainability assessment, environmental planning, climate change and cities, community based, low-carbon urban development, and planning for the developing countries. 